\title{
Study of Serotypes, Susceptibility to Macrolide and Virulence and Resistance Molecular Profiles in Invasive Strains of Streptococcus agalactiae in Two Argentine Provinces
}

\author{
Margarita Laczeski ${ }^{1,2 *}$, Marina Novosak ${ }^{1,2}$, Roxana Cannistraci Giolito ${ }^{3}$, Ana Littvik ${ }^{3}$, \\ Jorge Paván ${ }^{3}$, Viviana Villalba ${ }^{4}$, Marta Vergara ${ }^{1}$ \\ ${ }^{1}$ Department of Microbiology, Bacteriology, Faculty of Exact, Chemical and Natural Sciences, National \\ University of Misiones, Posadas, Argentina \\ ${ }^{2}$ Institute of Biotechnology, Faculty of Exact, Chemical and Natural Sciences, National University of Misiones \\ (INBIOMIS-FCEQyN-UNaM), Posadas, Argentina \\ ${ }^{3}$ Department of Microbiology, Medical Bacteriology and Virology, Faculty of Medical Sciences, National \\ University of Cordoba, Cordoba, Argentina \\ ${ }^{4}$ Public Hospital "Dr. Ramón Madariaga", Posadas, Argentina \\ Email: ${ }^{*}$ melaczeski@fceqyn.unam.edu.ar
}

Received 25 February 2015; accepted 7 April 2015; published 9 April 2015

Copyright @ 2015 by authors and Scientific Research Publishing Inc.

This work is licensed under the Creative Commons Attribution International License (CC BY).

http://creativecommons.org/licenses/by/4.0/

(c) (1) Open Access

\section{Abstract}

A study of invasive strains of Streptococcus agalactiae (GBS) from Cordoba and Misiones, Argentina; was conducted to determine serotypes, the susceptibility to macrolides and molecular profiles of virulence and resistance. We studied 17 strains, recovered from cerebrospinal fluid, blood and cellulite and, a strain of trophoblastic remnants from Misiones. The serotypes were determined by agglutination with sera and phenotypes of resistance to macrolide-lincosamide-streptogramin $B$ $\left(M L S_{B}\right)$, were determined with the double-disk test (D-test). The confirmation was performed by E-test by ERI and CLI respectively that determined the minimum inhibitory concentration (MIC). Results were interpreted as recommended by the Clinical and Laboratory Standards Institute (CLSI) 2013. Resistance genes: $e r m B$, ermTR and mefA and the virulence genes: bac, bca, rib, $\operatorname{lmb}$, hylB, $s c p B, f b s A, f b s B$ and $c y l B$ were investigated by conventional PCR. Serotype III (50\%) and Ia (50\%) were detected in Cordoba. One strain showed $\mathrm{cMLS}_{\mathrm{B}}$ phenotype, confirmed by MIC. The same strains showed a resistance gene ermB. All studied virulence genes were detected in $100 \%$ of

*Corresponding author.

How to cite this paper: Laczeski, M., et al. (2015) Study of Serotypes, Susceptibility to Macrolide and Virulence and Resistance Molecular Profiles in Invasive Strains of Streptococcus agalactiae in Two Argentine Provinces. Advances in Microbiology, 5, 230-243. http://dx.doi.org/10.4236/aim.2015.54021 
these strains. In Misiones, serotypes were III (72.7\%), Ia (18.2\%) and Ib (9.1\%). All strains were susceptible to CLI and ERI by D-test, confirmed by MIC. None of the strains showed resistance genes. Virulence genes $b c a$, rib, hylB, $\operatorname{lmb}$, fbs $A, f b s B$ and $c y l B$ were detected in $100 \%$ of the strains, bac in $\mathbf{8 1 . 8 \%}$ and $s c p B$ in $\mathbf{9 0 . 9 \%}$. Our results are in accordance with international data, associating higher frequency of serotype III of invasive neonatal disease followed by Ia. The presence of serotype Ib could indicate a regional difference for Misiones. We highlight the macrolides susceptibility in strains of Misiones and consistency in the results for D-test, MIC and PCR for the single strain resistant phenotype $c M L S_{B}$ from Cordoba. The virulence genes studied were presented with high frequency as expected for invasive strains.

\section{Keywords}

\section{Streptococcus agalactiae, Perinatal Infection, Macrolides, Resistence Genes, Virulence Genes}

\section{Introduction}

Streptococcus agalactiae (Lancefield group B streptococcal, GBS), initially described by Nocarrd and Mollereau in 1887 [1] was isolated from vaginal cultures in 1935, was listed as a human pathogen for the first time in 1938 as cause of fatal puerperal fever [2]. Since the 1970s emerges as an important agent of infections in patients with underlying chronic diseases, osseous infections and endocarditis, to become the most common cause of invasive bacterial infection during the neonatal period, causing sepsis, pneumonia and meningitis [3].

GBS is part of the human gastrointestinal tract and the female genital tract. Vaginal colonization rate in pregnant women is not equal between different geographical areas, the data world ranging from $5 \%$ to $30 \%$ [4], communicating data in the range of $1.4 \%$ to $18.15 \%$ for Argentina [5]. Published data for Misiones, a province of Argentina, show a colonization rate of $8.6 \%$ [6]. About $50 \%$ of babies born from these women are colonized with GBS during labor and 1\% develop a severe infection [5].

The disease severity in the neonate results in a factor of neonatal morbidity and mortality and increases the costs on public and private health [7].

With the objective of preventing morbidity and mortality of newborn, the Center for Disease Control and Prevention (CDC) publish consensus guidelines since 1996 and updating of 2010 recommends, again, two strategies with order to identify mothers colonized with GBS at the end of gestational age, and to prevent perinatal disease [8].

These strategies consist in identify the following risk factors: previous birth with invasive GBS disease, GBS in urine during pregnancy, premature delivery (before 37 weeks gestation), intrapartum temperature equal to or greater than $38^{\circ} \mathrm{C}$, break premature membrane equal to or greater than 18 hours and carrying GBS in the genital tract of pregnant women between 35 - 37 gestation weeks [9].

The implementation of these recommendations promoted the decrease in neonatal invasive disease in regions that have been adopted.

In Argentina, the search for GBS in all pregnant women with gestational age between 35 and 37 weeks, with or without risk factors, is obligatory according to the National Law No. 26.369 in the entire country since April 2008 [10].

The severity of neonatal disease is largely determined by a number of virulence factors including the ones encoded by the cps gene, which encode the capsule, and genes that encode surface proteins required for host-cell bacteria [11].

Besides of being an important virulence factor of GBS, polysaccharide capsule has a structure that allows its distinction in 10 serotypes (Ia, Ib, II, III, IV, V, VI, VII, VIII and IX), which are presented in combination with different surface proteins (antigenic) as $\alpha, \beta$ and Rib and C5a peptidase among others.

A characteristic of GBS strains is that most of the genes associated with the virulence encode proteins necessary for bacteria-host-cell interaction in the process of pathogenicity.

Surface proteins include among others a $\mathrm{C} \alpha$ - and $\beta \mathrm{C}$, Rib, HylB, Lmb, c5a peptidase and $\beta$-hemolysin [12].

The $\alpha$-C protein encoded by the bca gene is associated with adherence to the epithelial cell and $\beta$-C encoded 
by bac, to the invasion [13].

The Rib protein encoded by the rib gene is very similar to the $\alpha$-C protein and it is expressed by the majority of invasive strains.

The HylB protein encoded by the gene hylB is a hyaluronidase which cleaves hyaluronic acid, the main component of the extracellular matrix, contributing to the spread of GBS [14] [15].

Lmb protein encoded by the $\operatorname{lmb}$ gene mediates in the adherence to human laminin [16]. The bacterial binding to the extracellular matrix through Lmb seems important to GBS translocation through the intestinal epithelium and the blood brain barrier [17].

The C5a peptidase encoded by the $\operatorname{cspB}$ gene is a protein that plays an important role in the adherence and invasion of host cells and it is involved in the proteolytic inactivation of complement factor C5a [17].

The $\beta$-cyle hemolysin encoded by the cylE gene is a toxin that induces the cytolysis in the eukaryotic cells and promotes bacterial invasion through the epithelium and the endothelial walls, including the blood brain barrier [17]. It is associated with tissue injury and to the production of meningitis [3] [13].

The surface proteins antigens and the genes that encode them are considered important for epidemiological characterization of the strains.

The frequency of these proteins and the genes that encode them depends to origin of the strains (colonizing or invasive), study periods, geographical, and the social and ethnic origin of the studied population [18].

The invasion of host cells represents an important mechanism invasive GBS pathogenesis and the progression to pneumonia, sepsis and meningitis.

Recent researches show that one of the main ways of neonatal infection is rising by propagation of GBS in the amniotic fluid and the aspiration of this contaminated fluid by the fetus. After getting access to the respiratory tract, the bacteria can colonize and invade the lungs, causing pneumonia [19].

The GBS transmigration through the epithelial border allows fast access to the bloodstream and to the circulation to other organs and tissues reaching to the meninges [20].

Current studies have demonstrated the ability of GBS to invade human cells. However, the underlying fact of the invasion of the host cell is still poorly known [19].

It is known a wide range of surface proteins that contribute to the pathogenesis, most of these multifunctional proteins involved in adhesion, invasion and/or evasion of the immune response [21].

In many pathogenic bacteria, the invasion of host cells is mediated by bacterial surface proteins that recognize specific ligands in the extracellular matrix or on the surface of the host cell. There are several important interactions between the extracellular matrix of host and GBS reported and proposals for the adhesion and invasion [3].

It has been recently identified in GBS an adhesion protein to fibrinogen, which adheres strongly to the pulmonary epithelial cells and protects the bacteria from the opsonization in the human bloodstream. It is named FbsB protein encoded by the $f b s B$ gene [19].

A new protein, FbsA, encoded by the $f b s A$ gene protects the bacteria opsono-phagocytosis and promotes their adherence to epithelial cells and brain endothelium, allowing it to cross the blood brain barrier leading to meningitis [20].

The colonization and invasion of epithelial barrier is at least, in part, related to the ability of GBS to link human fibrinogen [19] [22] [23]. The strains that cause severe invasive infections can interact strongly with this protein [24].

The GBS capacity of binding to fibrinogen has been classically linked to the expression of two surface proteins, fbsB and fbsA [25]-[27]. The FbsA protein is likely to be sufficient to link the GBS to epithelial cells and to endothelial cells, but not enough to the cell invasion, which is a process for which is also required the FbsB protein [28].

The study of the above virulence factors could contribute to the development of a vaccine that offers protection to the newborn. In the world there is currently no commercially available vaccine against GBS, it is only being tested in the basis of in the serotype-dependent polysaccharide conjugates [29]. The development of an effective vaccine would be the best way to prevent GBS disease [1].

Since the observation of Lancefield in the 70s [30], working with animal models, based on the protection conferred by the $\mathrm{C}$ antigen against infection by SGB, the protein surface was implicated with the capsule as generating of a protective immune response. The study of these virulence factors could be used for the generation of maternal vaccines that would prevent neonatal disease [31] [32].

The knowledge of virulence factors involved that can be used as antigenic epitopes for the production of an 
effective vaccine could protect a large proportion of infants against GBS sepsis early and late onset and may also prevent stillbirths and premature births associated to infection [33].

The use of cell surface proteins of GBS in addition to the capsular polysaccharides for new vaccines represents an attractive alternative for the development of extensive independent serotype coverage and also offers new possibilities for the development of prophylactic and passive immune therapy [21].

The intrapartum prophylaxis (PIP) with penicillin or ampicillin prevents neonatal invasive disease for GBS once detected maternal colonization [31].

In those pregnant intolerant to penicillin, erythromycin (ERI) and clindamycin (CLI) administration are recommended.

In most cases, prophylaxis results in a significant decrease of neonatal invasive infections [34].

It has been identified two mechanisms of macrolide resistance in GBS.

The most common mechanism is the modification of the ribosomal target site by methylation and the efflux mechanism drug or active transport.

The methylation of 23S subunit of rRNA by erm (erythromycin ribosomal methylase) ermB, ermA (subclass ermTR) genes cause a conformational change in the prokaryotic ribosome and blocks binding of macrolides, lincosamides and streptogramin B to the binding site in the 50S subunit, leading it to resistence [35].

This mechanism gives macrolides-lincosamides and streptogramin $B\left(M L S_{B}\right)$ resistant. The methylases can be expressed constitutively (constitutive resistance phenotype $\mathrm{CMLS}_{\mathrm{B}}$ ) or in inducible form (inducible resistance phenotype iMLS $S_{B}$ ) [35].

The active efflux mechanism was described as mediated mefA and it confers resistance to macrolide lincosamide but not to streptogramin B (M phenotype) [36] [37].

The induction has been linked with the presence of cladinose in the macrolide 14 (ERI) and 15 atoms. The macrolides 16 atoms and CLI not induce the methylase activity because they lack this sugar. The CLI sensitivity seems to be affected by the presence of an inducer, so in presence of this mechanism the strains in study must be reported as resistant so it is not clinically effective [38].

As we noted above, the ability of GBS to generate resistance to ERI and CLI is reflected in resistance to MLS $\mathrm{B}_{\mathrm{B}}$ group, which has two variables, constitutive $\mathrm{CMLS}_{\mathrm{B}}$ and inducible iMLS $\mathrm{B}_{\mathrm{B}}$ resistance, both are related with expression of the erm genes.

The constitutive variable presents high level of resistance to any antimicrobial MLS $_{B}$ group, unlike induced resistance that only has macrolide resistance to 14 atoms (ERI) and to 15 atoms (azithromycin) and in vitro sensitivity to macrolides of 16 atoms, lincosamides (CLI) and streptogramin B.

In the iMLS $_{\mathrm{B}}$ strains the expression of the erm gene is induced by some compounds like the ERI, which is a powerful inductor to the iMLS $S_{\mathrm{B}}$ resistence, meanwhile the CLI is a weak inductor that acts slowly.

Therefore resistant strains appear iMLS $_{\mathrm{B}}$ in vitro susceptibility to CLI, but when used clinically produce in vivo induction of resistance with consequent therapeutic failure.

The therapeutic failure is explained because the CLI is a weak inductor, which leads in a long term, during the treatment, induces resistance itself.

The characteristic of ERI as a potent inductor of resistance allows us to use it in test to detect iMLS $S_{B}$.

The double disk test (D-test), recommended by the CLSI [39], allow the detection iMLS $_{\mathrm{B}}$ mechanism as evidence of phenotypic expression, useful to presage a mutation to a constitutive resistance in vivo [40]. These mechanisms cannot be detected using conventional methods in disk diffusion neither by dilution methods or conventional plates.

Molecular studies and sensitivity to ERI and to CLI of invasive GBS strains are important for the provinces of Argentina included in this study (Cordoba and Misiones), the region and our country (there are not existing data at the moment of this presentation), no progress has been made of these characteristics that included, in particular, the study of genes directly associated with central nervous system invasion.

The aim of the present study was determine the presence of resistance genes: ermB, mefTR and mefA of virulence: $b a c, b c a$, $r i b, h y l B, \operatorname{lmb}, \operatorname{csp} B, c y l B, f b s A$ and $f b s B$ and the sensitivity to macrolides in invasive strains GBS, contributing to knowledge of severe neonatal disease caused by this organism and the intimate bacteriahost interactions during invasion, adding prevention strategies already established by the World Health Organization and that directly involve developing countries with a view to producing an appropriate regional vaccine. 


\section{Materials and Methods}

\subsection{Invasive GBS Strains}

Seventeen strains of GBS invasive collection of the chair of bacteriology isolated from blood cultures and cerebrospinal fluid (CSF) were studied: 11 strains obtained from Madariaga Hospital Posadas (Period 2004-2011) and 6 strains of the Maternity Hospital of Córdoba (2011-2013). The strains were preserved in 20\% skim milk at $-80^{\circ} \mathrm{C}$ in order to preserve its original features, morphological and chemical, biochemical and genotypic.

\subsection{Biochemical and Serological Characterization of Group}

Conventional biochemical tests and commercial kit for latex agglutination (Phadebact Strep B Test International ETC, Bactus AB, Switzerland) were used to identify invasive strains of GBS.

GBS strains were recovered on agar plates supplemented with 5\% sheep blood. Beta hemolytic colonies were subjected to the following tests: Gram stain, catalase, CAMP test, hippurate hydrolysis, PYR (pyrrolidonyl aminopeptidase) and bile esculin.

The isolates of beta hemolytic Gram-positive cocci, with tests negative for catalase, bile esculin and PYR and; test positive for hydrolysis of hippurate and CAMP and SGB group serology were confirmed as GBS.

\subsection{Serotype Determination}

Agglutination test Statens Serum Institut (Strep-B. Latex. Copenhagen, Denmark) containing 10 serotypes (Ia, Ib, II, III, IV, V, VI, VII, VIII and IX) were used.

\subsection{Antimicrobial Susceptibility Testing}

Phenotypes of resistance to macrolides-lincosamide-streptogramin B $\left(\mathrm{MLS}_{\mathrm{B}}\right)$ with double-disk test (D-test) in Mueller-Hinton agar (Britania, Argentina) supplemented with 5\% sheep blood, were performed with ERI discs (15 $\mathrm{mg}$ ) and CLI ( $2 \mu \mathrm{g})$ provided by laboratories Britain, Argentina, according to recommendation and interpretation of Clinical and Laboratory Standards Institute (CLSI) [39].

The confirmation of ERI and CLI susceptibility was performed by E-test that determines the (MIC) minimum inhibitory concentration, with strips supplied by Oxoid, UK and Biomerieux, France; respectively.

The results were interpreted according to CLSI recommendations [39].

Staphylococcus aureus ATCC 25923 was used as control strain. The isolates and control strains were considered susceptible or resistant according to the cutoffs recommended by the Clinical and Laboratory Standards Institute (CLSI) [39].

\subsection{Extraction and Quality Assessment of DNA}

The Prokaryotic DNA extraction was performed with a $24 \mathrm{~h}$ bacterial culture in liquid medium according to the protocol of Sambrook [41] amended by Cariaga Martinez and Zapata [42]. The evaluation of the quality and quantity of extracted DNA was performed by electrophoresis runs in agarose gel at $1 \%$ stained with Gel-Red ${ }^{\circledR}$ (Biotium, Inc., US), in electrophoretic cuba (Electrophoresis Subsistem 70 Labnet International), then we proceeded to the observation of the bands in UV transilluminator (MUV Model 21-312-220).

\subsection{Detection of Resistance and Virulence Genes}

The primers used for the search of resistance and virulence genes are listed in Table 1 and Table 2 respectively. Both genes (virulence and resistance) were investigated by conventional PCR.

Their sequences were matched with GenBank and synthesized by Operon Molecules for Life (USA): ermB, ermTR and mefA, bac, bca, rib, hylB, Imb, and by Invitrogen (Korea): cspB, cylB, fbs $A$ and $f b s B$.

PCR products were visualized on agarose gels $2 \%$ using the same equipment as for assessing quality and quantity of genomic DNA, using MP (D0017 marker DNA fragments made up of 10 double-stranded DNA molecular size of 100 to 1000 pb-INBIO, Argentina). Bands observed with MP in 2\% agarose gel, electrophoresis stained with GelRed ${ }^{\circledR}$, are shown in Figure 1.

For resistance genes positive controls transferred by the Institute of Reference in Argentina "Dr. Carlos G. 
Table 1. Secuence of primers used in PCR to amplify the resistance genes in isolates of Streptococcus agalactiae.

\begin{tabular}{cccccc}
\hline Genes & Forward 5' $\mathbf{~} \mathbf{3}^{\prime}$ & Reverse $\mathbf{5}^{\prime} \mathbf{~} \mathbf{3}^{\prime}$ & Amplicon (bp) & TM $\left(\mathbf{~}^{\circ} \mathbf{C}\right)$ & GenBank \\
\hline ermB & GAAAAAGTACTCAACCAAATA & AGTAATGGTACTTAAATTGTTAC & 489 & 50 & DQ355148.1 \\
ermTR & TTGGGTCAGGAAAAGGA & GGGTGAAAATATGCTCG & 385 & 50 & AF00216.1 \\
mefA & GGTATCTTTAATCACTAGTGC & TTCTTCTGGTACTAAAAG & 373 & 50 & DQ445272.1 \\
\hline
\end{tabular}

Table 2. Secuence of primers used in PCR to amplify the virulence genes in isolates of Streptococcus agalactiae.

\begin{tabular}{cccccc}
\hline Genes & Forward 5' $\mathbf{-} \mathbf{3}^{\prime}$ & Reverse $\mathbf{5}^{\prime} \mathbf{-} \mathbf{3}^{\prime}$ & Amplicon (bp) & TM $\left({ }^{\circ} \mathbf{C}\right)$ & GenBank \\
\hline$b a c$ & TGTAAAGGACGATAGTGTGAAGAC & CATTTGTGATTCCCTTTTGC & 530 & 50 & AB221536.1 \\
$b c a$ & CAGGAAGGGGAAACAACAGTAC & GTATCCTTTGATCCATCTGGATACG & 535 & 50 & M97256.1 \\
$r i b$ & CAGGAAGTGCTGTTACGTTAAAC & CGTCCCATTTAGGGTCTTCC & 369 & 50 & U58333.1 \\
$h y l B$ & TTATCATCCAGCGCCTCCTAG & GTGGTGATAACTGACTTCTTGGGA & 245 & 50 & Y15903.1 \\
$l m b$ & GACGCAACACACGGCAT & TGATAGAGCACTTCCAAATTTG & 300 & 50 & AF062533.1 \\
$c s p B$ & AGCCATATGCTGCGATCTCT & GGGTTGAACCAAGTGTGCTT & 198 & 58 & U56908.1 \\
$c y l B$ & GGGCTGCAGGTATTATCGAA & ATTTCCACCAAAAGCAAACG & 176 & 58 & AF093787.2 \\
$f b s A$ & TGTAGCTAATGGACCGATGTT & TTTTCATTGCGTCTCAAACC & 156 & 58 & AJ437619.1 \\
$f b s B$ & ACAACTGCGGAAATGACCTC & ACGAGCGACGTTGAATTCTT & 186 & 58 & HQ267707.1 \\
\hline
\end{tabular}

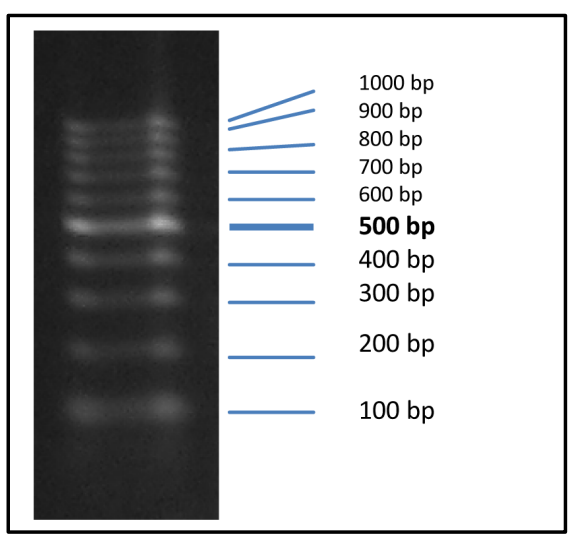

Figure 1. MP (D0017 marker DNA fragments made up of 10 double-stranded DNA molecular size of 100 to 1000 pb-INBIO, Argentina): Bands observed by $2 \%$ agarose gel, electrophoresis stained with GelRed ${ }^{\circledR}$.

Malbrán” (National Institute of Infectious Diseases-ANLIS) were used: AZ1 Streptococcus pneumoniae: mefA and ermB genes. Streptococcus agalactiae 6394: ermTR gene. For the virulence genes (bac, bca, rib, hylB and lmb) we worked with internal positive controls obtained after sequencing by Invitrogen, Korea; PCR products and collating sequences in the BLASTn program. As a positive control $f b s A$ and $f b s B$ genes strain SGB43BB, the PCR product was previously sequenced by Macrogen (Korea) and the sequence obtained and published in the Bioedit 7.1 freeware was used, was checked in the BLASTn program NCBI obtaining overall sequence alignment and identity $100 \%$.

The results were statistically analyzed with the R program using Fisher's exact test to assess whether there are significant differences between strains of Misiones and Cordoba.

\section{Results}

\subsection{Determination of Serotype}

GBS strains of Misiones: The serotypes found in invasive strains were serotype III (72.7\%), Ia (18.2\%) and Ib 
(9.1\%). GBS strains of Cordoba: serotype III (50\%) and Ia (50\%) were detected.

\subsection{Macrolide Susceptibility Testing by Diffusion (D-Test) and MIC}

GBS strains of Misiones: The 11 strains were susceptible to ERI and CLI by D-test and confirmation by CIM gave similar results with ranges from 0.003 to $0.12 \mu \mathrm{g} / \mathrm{ml}$ for ERI and from 0.032 to $0.094 \mu \mathrm{g} / \mathrm{ml}$ for CLI. GBS strains of Cordoba: Two strains belonging to the same patient and isolated from different clinical specimens (skin and blood), showed resistance phenotype $\mathrm{CMLS}_{\mathrm{B}}$ (ERI and CLI $=6 \mathrm{~mm}$ ) confirmed by CIM (ERI and CLI $=8 \mu \mathrm{g} / \mathrm{ml}$ ) for both strains, indicating that it is insulated with antibiotype identical.

Macrolide susceptibility of strains of Misiones is highlight; MIC results confirmed the correlation between phenotype detected by D-test and the results obtained by MIC for resistant strains of Cordoba.

\subsection{Resistance Genes}

GBS strains of Misiones: None of the invasive strains presented the macrolide resistance genes studied. GBS strains of Cordoba: Strains with phenotype characterized by D-test $\mathrm{CMLS}_{\mathrm{B}}$ confirmed by MIC also presented the ermB gene associated with such resistance to macrolides described as constitutive. The serotype detected for these strains was III.

Figure 2 shows agarose gel 2\% electrophoresis of the PCR products, resistance genes and invasive strains studied.

\subsection{Virulence Genes}

GBS strains of Misiones: In the 11 strains studied, virulence genes $b c a$, rib, hylB, $\operatorname{lmb}$, fbsA, fbsB and cylB were detected in $100 \%$, bac $81.8 \%$ and $s c p B$ at $90.9 \%$.

GBS strains of Cordoba: All studied virulence genes were detected in $100 \%$ of these 6 strains.

The results obtained by agarose gel electrophoresis $2 \%$ for the virulence genes studied by PCR are shown in Figure 3.

The results for virulence genes found by PCR technique for invasive GBS isolates by serotype are shown in Table 3.

The results obtained by D-test, MIC and detail of the detected phenotypes are showed in Table 4.

\section{Discussion}

In GBS virulence an important determinant is the capsular polysaccharide, specific type, which prevents the de-

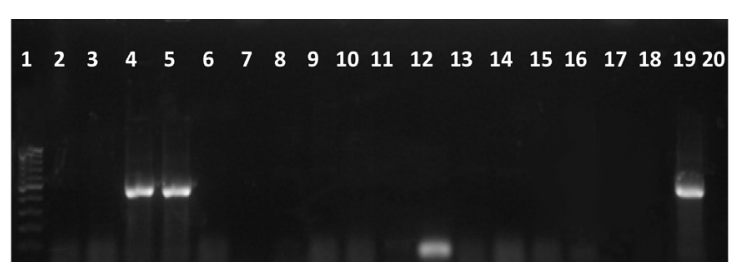

(a)

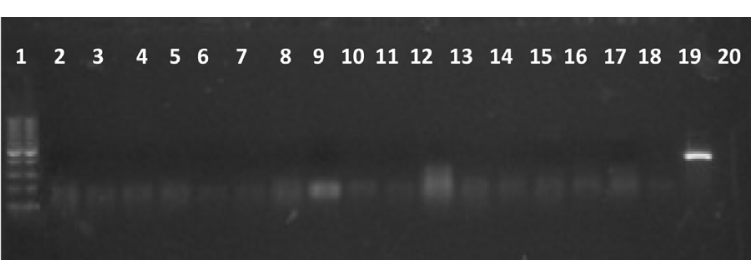

(b)

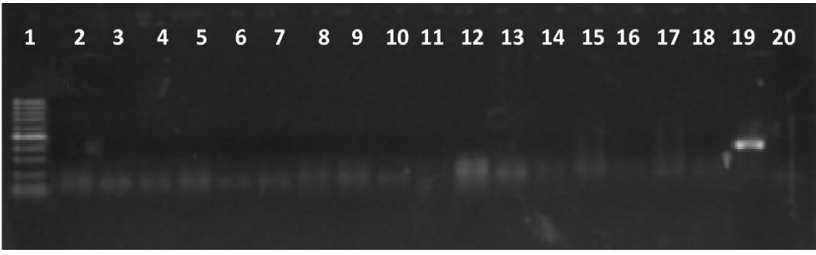

(c)

Figure 2. Genes for resistance to macrolides. Agarose gel electrophoresis $2 \%$ of the PCR products for genes: (a) ermB, (b) ermTR, (c) mefA. First Street, molecular weight marker, marker DNA (D0017) 100 - 1000 pb-INBIO, Argentina; Streets 2 - 18, strains Streptococcus agalactiae (GBS) Invasive: 1, 2, 3, 4, 5 , 7 (Cordoba), 42, 43, 47, 74, 04669, 02963, 06150, 06151, P6550, 06270, 06272 (posadas); 19th Street positive [Streptococcus pneumoniae AZ1 to ermB genes (469 bp) and genes mefA (373 bp), Streptococcus agalactiae 6394 to ermTR gene (385 bp)]; last street, negative control. 


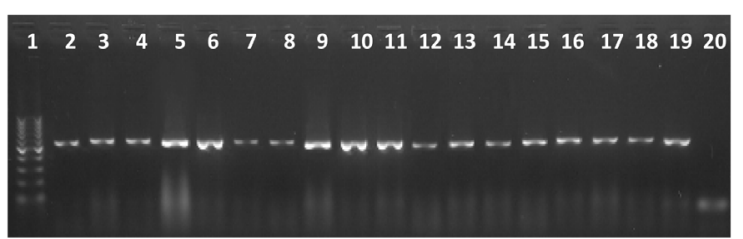

(a)

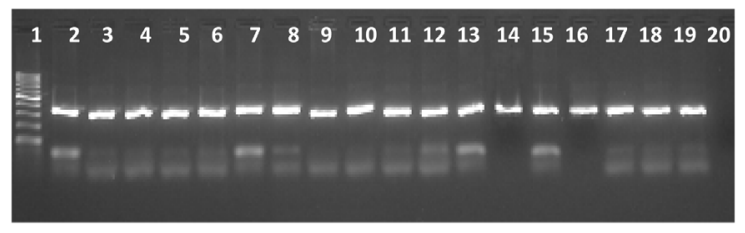

(c)

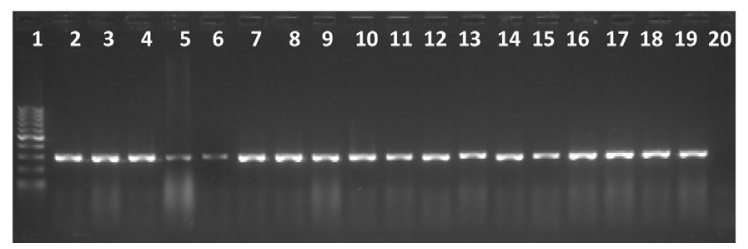

(e)

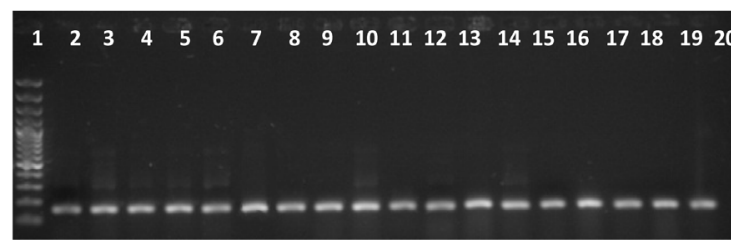

(g)

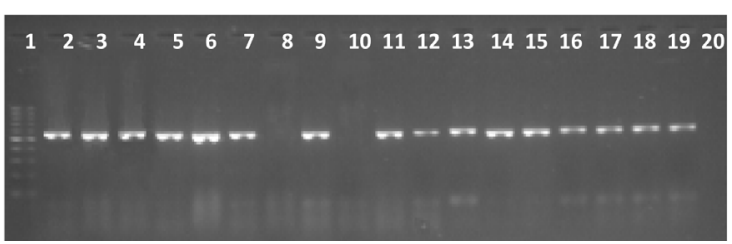

(b)

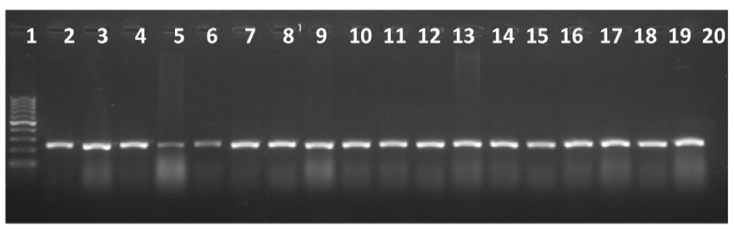

(d)

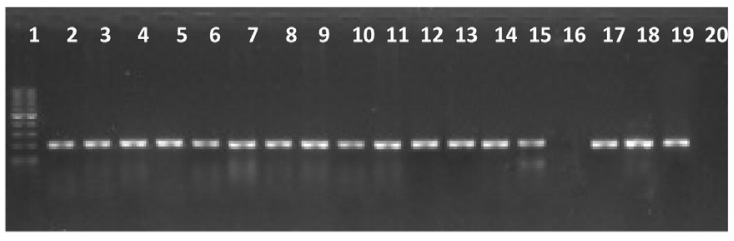

(f)

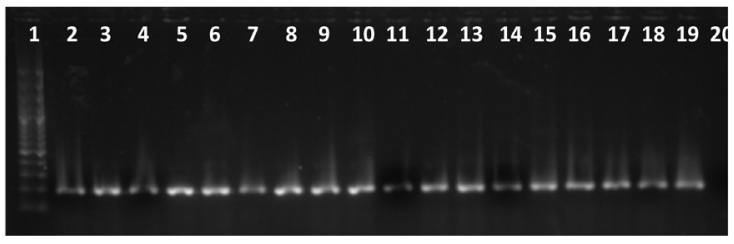

(h)

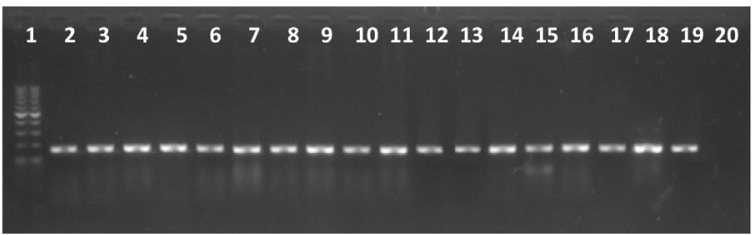

(i)

Figure 3. Virulence genes. Agarose gel electrophoresis $2 \%$ of the PCR products for genes: (a) bca, (b) bac, (c) rib, (d) hylB, (e) $\operatorname{lmb}$, (f) $c s p B$, (g) fbsA, (h) fbsB, and (i) cylB. First Street, molecular weight marker, marker DNA (D0017) 100 - 1000 pb-INBIO, Argentina; Streets 2 - 18, strains Streptococcus agalactiae (GBS) Invasive: 1, 2, 3, 4, 5,7 (Cordoba), 42, 43, 47, 74, 04669, 02963, 06150, 06151, P6550, 06270, 06272 (Posadas); 19th Street, positive control [SGB221 for bca (535 bp), hylB (245 bp) and lmb (300 bp) genes; SGB264 for bac (520 bp) gene; SGB43BB for rib (369 bp), cspB (198 bp), fbsA (156 bp), fbsB (186 bp) and cylB (176 bp) genes]; last street, negative control.

position of complement factor and therefore inhibits opsonophagocytosis. Ten different capsular serotypes, Ia, Ib and II to IX, have been identified in GBS with variability in the geographical distribution [43]. The serotypes that commonly cause neonatal infections are III, Ia, and V [44].

In agreement with other authors [44]-[46] our results indicate detection of serotype III and Ia in GBS strains isolated from infants. These results coincide with international studies that evaluating the distribution of serotypes in invasive strains of GBS which indicate at serotype III (66\%) as the most common in strains isolated in infants [44]-[46]. A study performed in Spain, reported greater frequency of serotype III (43.47\%) followed by serotype Ia (30.4\%) [47]. Another study also revealed a high frequency of serotype III (48.9\%) followed by serotypes Ia $(22.9 \%)$ [48].

Our results do not agree with other authors who found the following serotypes of GBS invasive isolates: III (50\%), II (27\%), V (14\%) and Ia (9\%) [49]. 
Table 3. Results of search for virulence genes by PCR for Streptococcus agalactiae by serotype.

\begin{tabular}{|c|c|c|c|c|c|c|c|c|c|c|c|c|}
\hline \multirow{2}{*}{ No. } & \multirow{2}{*}{ ID } & \multirow{2}{*}{ Serotype } & \multirow{2}{*}{ Province } & \multicolumn{9}{|c|}{ Virulence Genes } \\
\hline & & & & $b c a$ & bac & rib & hylB & $\operatorname{lmb}$ & $\operatorname{csp} B$ & $f b s A$ & $f b s B$ & cylB \\
\hline 1 & 42 & III & Misiones & + & - & + & + & + & + & + & + & + \\
\hline 2 & 43 & III & Misiones & + & + & + & + & + & + & + & + & + \\
\hline 3 & 47 & $\mathrm{Ib}$ & Misiones & + & - & + & + & + & + & + & + & + \\
\hline 4 & 74 & III & Misiones & + & + & + & + & + & + & + & + & + \\
\hline 5 & 4663 & III & Misiones & + & + & + & + & + & + & + & + & + \\
\hline 6 & 2963 & Ia & Misiones & + & + & + & + & + & + & + & + & + \\
\hline 7 & 6150 & III & Misiones & + & + & + & + & + & + & + & + & + \\
\hline 8 & 6151 & III & Misiones & + & + & + & + & + & + & + & + & + \\
\hline 9 & P6550 & Ia & Misiones & + & + & + & + & + & - & + & + & + \\
\hline 10 & 6270 & III & Misiones & + & + & + & + & + & + & + & + & + \\
\hline 11 & 6272 & III & Misiones & + & + & + & + & + & + & + & + & + \\
\hline 12 & 1 & Ia & Cordoba & + & + & + & + & + & + & + & + & + \\
\hline 13 & 2 & Ia & Cordoba & + & + & + & + & + & + & + & + & + \\
\hline 14 & 3 & III & Cordoba & + & + & + & + & + & + & + & + & + \\
\hline 15 & 4 & III & Cordoba & + & + & + & + & + & + & + & + & + \\
\hline 16 & 5 & Ia & Cordoba & + & + & + & + & + & + & + & + & + \\
\hline 17 & 7 & III & Cordoba & + & + & + & + & + & + & + & + & + \\
\hline
\end{tabular}

ID: Identification number of laboratory. (+): Presence; (-): Absence.

Table 4. Results serotype, susceptibility testing Erythromycin and Clindamycin (Diffusion test, D-test, MIC and resistance genes) for invasive GBS strains isolated from Posadas and Cordoba.

\begin{tabular}{|c|c|c|c|c|c|c|c|c|c|c|c|c|}
\hline \multirow{2}{*}{ No. } & \multirow{2}{*}{ ID } & \multirow{2}{*}{ Sample } & \multirow{2}{*}{ Serotype } & \multicolumn{2}{|c|}{ Diffusion (mm) } & \multirow{2}{*}{ D-Test } & \multirow{2}{*}{ Phenotype } & \multicolumn{2}{|c|}{$\mathrm{MIC} \mu \mathrm{g} / \mathrm{ml}$} & \multicolumn{3}{|c|}{ Resistence Genes (PCR) } \\
\hline & & & & ERI & CLI & & & ERI & CLI & ermB & ermTR & mefA \\
\hline 1 & 42 & CSF & III & 27 & 32 & NEG & N/D & 0.12 & 0.064 & - & - & - \\
\hline 2 & 43 & BLOOD & III & 30 & 29 & NEG & N/D & 0.15 & 0.047 & - & - & - \\
\hline 3 & 47 & CSF & $\mathrm{Ib}$ & 30 & 31 & NEG & N/D & 0.06 & 0.034 & - & - & - \\
\hline 4 & 74 & BLOOD & III & 27 & 29 & NEG & N/D & 0.003 & 0.032 & - & - & - \\
\hline 5 & 4663 & BLOOD & III & 25 & 24 & NEG & $\mathrm{N} / \mathrm{D}$ & 0.12 & 0.064 & - & - & - \\
\hline 6 & 2963 & BLOOD & Ia & 26 & 28 & NEG & N/D & 0.06 & 0.064 & - & - & - \\
\hline 7 & 6150 & BLOOD & III & 25 & 24 & NEG & N/D & 0.06 & 0.064 & - & - & - \\
\hline 8 & 6151 & CSF & III & 24 & 24 & NEG & N/D & 0.06 & 0.094 & - & - & - \\
\hline 9 & P6550 & ABORTION & Ia & 30 & 25 & NEG & $\mathrm{N} / \mathrm{D}$ & 0.12 & 0.064 & - & - & - \\
\hline 10 & 6270 & BLOOD & III & 25 & 24 & NEG & N/D & 0.06 & 0.064 & - & - & - \\
\hline 11 & 6272 & CSF & III & 25 & 24 & NEG & N/D & 0.06 & 0.064 & - & - & - \\
\hline 12 & 1 & BLOOD & Ia & 24 & 22 & NEG & $\mathrm{N} / \mathrm{D}$ & 0.12 & 0.094 & - & - & - \\
\hline 13 & 2 & CSF & Ia & 24 & 23 & NEG & N/D & 0.12 & 0.064 & - & - & - \\
\hline 14 & 3 & CELLULITE & III & 6 & 6 & N/D & $\mathrm{cMLS}_{\mathrm{B}}$ & 8 & 8 & + & - & - \\
\hline 15 & 4 & BLOOD & III & 6 & 6 & N/D & $\mathrm{CMLS}_{\mathrm{B}}$ & 8 & 8 & + & - & - \\
\hline 16 & 5 & BLOOD & Ia & 24 & 22 & NEG & N/D & 0.12 & 0.064 & - & - & - \\
\hline 17 & 7 & CSF & III & 27 & 26 & NEG & N/D & 0.12 & 0.062 & - & - & - \\
\hline
\end{tabular}

CSF: cerebrospinal fluid; BLOOD: blood cultures; ABORTION: trophoblastic remains; CELLULITE: puncture skin and soft tissue; ID: identification number of laboratory; ERI: erythromycin; CLI: clindamycin; N/D: not detected; iMLS $\mathrm{B}_{\mathrm{B}}$ : inducible phenotype; $\mathrm{cMLS}_{\mathrm{B}}$ : constitutive phenotype. $(+)$ : Presence; (-): Absence. 
Contrary to most international studies did not detect GBS serotype V in these strains, also related to the invasive potential of SGB [44]-[49].

The detection of GBS serotype Ib in a strain isolated from blood cultures may indicate a regional difference for Argentina. This should be considered in future studies with a larger number of isolates.

In the present work, the virulence genes investigated were presented with high frequency as expected for invasive strains and in accordance with other authors [33] [50]. We have not found similar studies involving the search for all virulence genes described in this work to isolates of perinatal infection.

The bac and $s c p B$ genes were detected more frequently in strains of Cordoba, although it is not possible to indicate whether there are statistically significant differences between the two provinces because of the small sample size. The $f b s A, f b s B$ and $c y l B$ genes, genes directly associated with invasive procedures, were detected in $100 \%$ of the strains studied.

In this study $s c p B, I m b$, hylB, rib, bca and bac genes were detected more frequently that in studies performed by other authors [18] [51]. This could be due to the disparity in the number and kind of worked strains (our study did not include colonizing strains isolated from pregnant women). These differences may also be due to geographical variations or temporal differences in distribution of capsular serotypes of GBS strains, as already described by different investigators [52]-[55].

GBS adhesion to epithelial cells is a key event in the infection process that allows colonization of the epithelial surfaces [45]. Following colonization, the bacteria can eventually penetrate the epithelial barrier and spread to the bloodstream and into the deeper tissues. The adhesion is often mediated by specific interactions between proteins and extracellular matrix components and streptococcal cell wall [19].

Recent international studies have characterized two GBS proteins, FbsA and FbsB, involved in adhesion and/or invasion of host cells, allowing bacterial binding to human fibrinogen [19] [26]. Our results agree with other authors for $f b s A$ gene and defer for $f b s B$ gene [28]. The observed differences could be explained by the study population. It included GBS strains isolated from pregnant women and infants, whereas our study included only invasive strains producing neonatal infection.

The FbsA protein is important for the binding of GBS to fibrinogen [19] and the role of FbsB protein is highlight in the overall process of host cell invasion giving a first idea of the underlying facts necessary for the successful establishment of infection. Some author found that the amino acid sequences of this protein is highly immunogenic and show little variation between strains [21]. This coupled with the understanding of the GBS virulence mechanisms at the molecular level, can contribute to the development of an effective vaccine against these bacteria [50].

The study of genes encoding surface proteins is important for epidemiological analysis of the circulating strains in the province because the knowledge of the distribution and frequency, as well as the emergence of new strains in a region, is a fundamental requirement in the formulation of vaccine strategies [56].

The conjugate vaccines have been evaluated on the basis of capsular polysaccharides from GBS serotypes of clinically relevant [43].

The use of cell surface proteins of GBS is an alternative in addition to the capsular polysaccharides for the development of vaccines with broad coverage (independent serotype) and also offers new possibilities for the development of prophylactic and passive immune therapy [57].

No information on similar studies at regional and national level to date was found.

From the stand point of the prevention of perinatal GBS infection, it has been implemented screening pregnant colonized between weeks 35 - 37 of gestation. The usual treatment and prophylaxis of GBS infections is penicillin, but in allergic patients the alternative treatment are macrolides [58].

In GBS are known two macrolide resistance mechanisms [59] [60] encoded by three genes: ermB, and mefA ermTR. The ermB and ermTR genes encoding a 23S rRNA methylase altering binding to the target of the antibiotic and expressed as resistance to macrolides, lincosamides and streptogramin $\mathrm{B}\left(\mathrm{MLS}_{\mathrm{B}}\right)$; constitutively $\left(\mathrm{CMLS}_{\mathrm{B}}\right)$ or inducible (iMLS $\mathrm{B}_{\mathrm{B}}$ ) respectively. The mefA genes encoding efflux pump expressing resistance to erythromycin but not to lincosamides and streptogramin (M phenotype).

It is noteworthy that in GBS strains studied and associated with invasive disease in neonates, full traceability was obtained in the study of the sensitivity therefore phenotypic, confirmatory and molecular methods.

Two strains of the same patient and isolated from different samples (blood and skin) presented clinical macrolide resistance phenotype through D-test and confirmed by CIM and detection of ermB gene, being $100 \%$ correlation between phenotype and genotype: $\mathrm{CMLS}_{\mathrm{B}}$-ermB. This situation varies in other works [61]. 
Our results indicate $100 \%$ sensitivity in isolates from neonates to the province of Misiones and 20\% of ERI and CLI resistance in GBS strains isolated in the province of Cordoba. The resistance detected agrees with other authors [62], which are in a study that included 150 invasive strains of GBS $22 \%$ of the genes associated with macrolide resistance.

Some authors found an increased resistance to ERI of $20.2 \%$ in 2007 to $35.3 \%$ in 2010 , associated mainly to capsular serotype $\mathrm{V}$ and ermB genotype [63].

Surveillance of resistance is important because in recent years it has been reported an increased resistance to macrolides [64].

The distribution of GBS serotypes depends on the geographic region and ethnicity of the pregnant women and macrolide resistance, thereof is subject to changes in the policies of antimicrobial use in different regions.

The broadcasting of antimicrobial resistance of GBS, seems to include both the clonal spread of resistant strains as well as horizontal gene transfer, i.e., these resistance genes can move between organisms and be widely publicized, so we agree with other authors [35] in which a permanent monitoring of resistance in GBS not only to characterize phenotypically and genotypically strains but also it is necessary to know the acquisition of new resistance mechanisms.

The study of carrying implemented in pregnant at the end of their gestational age and intrapartum antimicrobial has produced significant reductions in early disease [65]. In this study, that explains the low number of strains recovered.

\section{Conclusions}

The virulence genes studied are presented with high frequency as it was expected for strains isolated from invasive infections in neonates. The bac and $s c p B$ genes were detected more frequently in the strains of Cordoba, although it is not possible to indicate whether there are statistically significant differences between the two regions due to the small sample size. Genes: $f b s A, f b s B$ and $c y l B$, genes directly related to invasive procedures, were detected in $100 \%$ of the strains studied.

The level of carrying virulence genes detected may suggest its inclusion as antigenic determinants in the development of a regional vaccine.

Serotypes III, Ia and Ib of GBS were detected in Misiones and III and Ia in Cordoba. Our results agree so far with data published in different world regions associating a higher frequency of serotype III to invasive neonatal disease, followed by the serotype Ia. The presence of serotype Ib may indicate a regional difference for Argentina. The serotype V in invasive strains of GBS was not detected in this study.

Epidemiological surveillance of circulating serotypes and carrying and expression of virulence genes in strains of GBS in the region it is important to contribute to the study of disease by GBS and to be incorporated into the development of a regional vaccine.

We highlight the Macrolide susceptibility in strains of Misiones and consistency in the results for D-test, MIC and PCR for the resistant phenotype $\left(\mathrm{CMLS}_{\mathrm{B}}\right)$ strain of Cordoba. Know the profile of antimicrobial susceptibility is a good tool to have a therapeutic treatment success.

\section{References}

[1] Tara, C. and Smith, T.C. (2007) Deadly Diseases and Epidemics. Chelsea House, New York, 57-58.

[2] Heath, P. and Schuchat, A. (2007) Perinatal Group B Streptococcal Disease. Best Practice \& Research Clinical Obstetrics and Gynaecology, 21, 411-424. http://dx.doi.org/10.1016/j.bpobgyn.2007.01.003

[3] Lindhal, G., Stalhammar-Carlemalm, M. and Areschoug, T. (2005) Surface Proteins of Streptococcus agalactiae and Related Proteins in Other Bacterial Pathogens. Revista Argentina De Microbiologia, 18, 102-127. http://dx.doi.org/10.1128/CMR.18.1.102-127.2005

[4] Tamariz Ortiz, J.H., Obregón Calero, M., Jara Aguirre, J.C., Diaz Herrera, J. and Jefferson Cortes, L. (2004) Colonización vaginal y anorrectal por Streptococcus agalactiae en gestantes de los Hospitales Nacionales Cayetano Heredia y Arzobispo Loayza. Revista Medica Herediana, 15, 144-150.

[5] García, S.D., Eiseth, M.C., Lazzo, M.J., Copolillo, E., Barata, A.D., De Torres, R. and Vay, C.A. (2003) Group B Streptococcus Carriers among Pregnant Women. Revista Argentina De Microbiologia, 35, 183-187.

[6] Oviedo, P., Pegels, E., Laczeski, M., Quiroga, M. and Vergara, M. (2013) Phenotypic and Genotypic Characterization of Streptococcus agalactiae in Pregnant Women. First Study in a Province of Argentina. Brazilian Journal of Microbi- 
ology, 44, 253-258. http://dx.doi.org/10.1590/S1517-83822013005000030

[7] Cruz, M.O., Doren, A.V.,Tapia, J.L. and Abarzua, F.C. (2008) Sepsis Neonatal por Streptococcus Grupo B. Revista Chilena de Pediatría, 79, 462-470. http://dx.doi.org/10.4067/S0370-41062008000500003

[8] Centers for Disease Control and Prevention (2010) Prevention of Perinatal Group B: Revised Guidelines from CDC. MMWR Recommendations and Reports, 59, 1-31.

[9] Morin, C., White, K. and Schuchat, A. (2005) Perinatal Group B Streptococcal Disease Prevention, Minnesota. Emerging Infectious Diseases, 11, 1467-1469. http://dx.doi.org/10.3201/eid1109.041109

[10] Ley Nacional No 26.369 (2008). http://test.e-legis-ar.msal.gov.ar/leisref/public/search.php?type=ley/\%285\%29\&number=26369\&day=16\&month=04\& year $=2008$

[11] Udo, E.E., Boswihi, S.S. and Al-Sweih, N. (2013) Genotypes and Virulence Genes in Group B Streptococcus Isolated in the Maternity Hospital, Kuwait. Medical Principles and Practice, 22, 453-457. http://dx.doi.org/10.1159/000349932

[12] Edwards, M.S. and Baker, C.J. (2006) Streptococcus agalactiae (Estreptococos del grupo B). In: Bennett, J.E., Dolin, R. and Mandell, G.L., Eds., Enfermedades Infecciosas, Principios y Prácticas, Elsevier España S.A., Madrid, 24232434.

[13] Dutra, V.G., Alves, V.M., Olendzki, A.N., Dias, C.A., De Bastos, A.F., Santos, G.O., et al.(2014) Streptococcus agalactiae in Brazil: Serotype Distribution, Virulence Determinants and Antimicrobial Susceptibility. BMC Infectious Diseases, 14, 323-330. http://dx.doi.org/10.1186/1471-2334-14-323

[14] Wang, Z., Guo, C., Xu, Y., Liu, G., Lu, C. and Liu, Y. (2014) Two Novel Functions of Hyaluronidase from Streptococcus agalactiae Are Enhanced Intracellular Survival and Inhibition of Proinflammatory Cytokine Expression. Infection and Immunity, 82, 2615-2625. http://dx.doi.org/10.1128/IAI.00022-14

[15] Bohnsack, J., Takahashi, S., Detrick, S., Pelinka, L., Hammitt, L., Aly, A., Whiting, A. and Adderson, E. (2001) Phylogenetic Classification of Serotype III Group B Streptococci on the Basis of hylB Gene Analysis and DNA Sequences Specific to Restriction Digest Pattern Type III-3. The Journal Infectious Diseases, 183, 1694-1697. http://dx.doi.org/10.1086/320717

[16] Zhang, Y., Shao, Z., Wang, J., Wang, L., Li, X., Wang, C., Tang, J. and Pan, X. (2014) Prevalent Distribution and Conservation of Streptococcus suis Lmb Protein and Its Protective Capacity against the Chinese Highly Virulent Strain Infection. Microbiological Research, 169, 395-401. http://dx.doi.org/10.1016/j.micres.2013.09.007

[17] Landwehr-Kenzel, S. and Henneke, P. (2014) Interaction of Streptococcus agalactiae and Cellular Innate Immunity in Colonization and Disease. Frontiers in Immunology, 5, 519.

[18] Manning, S.D., Ki, M., Marrs, C.F., Kugeler, K.J., Borchardt, S.M., Baker, C.J., et al. (2006) The Frequency of Genes Encoding Three Putative Group B Streptococcal Virulence Factors among Invasive and Colonizing Isolates. BMC Infectious Diseases, 6, 116. http://dx.doi.org/10.1186/1471-2334-6-116

[19] Schubert, A., Zakikhany, K., Pietrocola, G., Meinke, A., Speziale, P. and Eikmanns, B.J. (2004) The Fibrinogen Receptor FbsA Promotes Adherence of Streptococcus agalactiae to Human Epithelial Cells. Infection and Immunity, 72, 6197-6205. http://dx.doi.org/10.1128/IAI.72.11.6197-6205.2004

[20] Doran, K.S. and Nizet, V. (2004) Molecular Pathogenesis of Neonatal Group B Streptococcal Infection: No Longer in Its Infancy. Molecular Microbiology, 54, 23-31. http://dx.doi.org/10.1111/j.1365-2958.2004.04266.X

[21] Meinke, A.L., Senn, B.M., Visram, Z., Henics, T.Z., Minh, D.B. and Schuler, W. (2010) Immunological Fingerprinting on Group B Streptococci: From Circulating Human Antibodies to Protective Antigens. Vaccine, 28, 6997-7008. http://dx.doi.org/10.1016/j.vaccine.2010.08.041

[22] Tenenbaum, T., Bloier, C., Adam, R., Reinscheid, D.J. and Schroten, H. (2005) Adherence to and Invasion of Human Brain Microvascular Endothelial Cells Are Promoted by Fibrinogen-Binding Protein FbsA of Streptococcus agalactiae. Infection and Immunity, 73, 4404-4409. http://dx.doi.org/10.1128/IAI.73.7.4404-4409.2005

[23] Rivera, J., Vannakambadi, G., Höök, M. and Speziale, P. (2007) Fibrinogen-Binding Proteins of Gram-Positive Bacteria. Thrombosis and Haemostasis, 98, 503-511. http://dx.doi.org/10.1160/TH07-03-0233

[24] Dramsi, S., Morello, E., Poyart, C. and Trieu-Cuot, P. (2012) Epidemiologically and Clinically Relevant Group B Streptococcus Isolates Do Not Bind Collagen but Display Enhanced Binding to Human Fibrinogen. Microbes and Infection, 14, 1044-1048. http://dx.doi.org/10.1016/j.micinf.2012.07.004

[25] Schubert, A., Zakikhany, K., Schreiner, M., Frank, R., Spellerberg, B., et al. (2002) A Fibrinogen Receptor from Group B Streptococcus Interacts with Fibrinogen by Repetitive Units with Novel Ligand Binding Sites. Molecular Microbiology, 46, 557-569. http://dx.doi.org/10.1046/j.1365-2958.2002.03177.x

[26] Gutekunst, H., Eikmanns, B.J. and Reinscheid, D.J. (2004) The Novel Fibrinogen-Binding Protein FbsB Promotes Streptococcus agalactiae Invasion into Epithelial Cells. Infection and Immunity, 72, 3495-3504. 
http://dx.doi.org/10.1128/IAI.72.6.3495-3504.2004

[27] Al Safadi, R., Mereghetti, L., Salloum, M., Lartigue, M.F., Virlogeux-Payant, I., et al. (2011) Two-Component System RgfA/C Activates the FbsB Gene Encoding Major Fibrinogen-Binding Protein in Highly Virulent CC17 Clone Group B Streptococcus. PLoS ONE, 6, e14658. http://dx.doi.org/10.1371/journal.pone.0014658

[28] Rosenau, A., Martins, K., Amor, S., Gannier, F., Lanotte, P., et al. (2007) Evaluation of the Ability of Streptococcus agalactiae Strains Isolated from Genital and Neonatal Specimens to Bind to Human Fibrinogen and Correlation with Characteristics of the FbsA and FbsB Genes. Infection and Immunity, 75, 1310-1317. http://dx.doi.org/10.1128/IAI.00996-06

[29] Madhi, S.A., Dangor, Z., Heath, P.T., Schrag, S., Izu, A., Sobanjo-Ter Meulen, A., et al. (2013) Considerations for a Phase-III Trial to Evaluate a Group B Streptococcus Polysaccharide-Protein Conjugate Vaccine in Pregnant Women for the Prevention of Early- and Late-Onset Invasive Disease in Young-Infants. Vaccine, 31, D52-D57. http://dx.doi.org/10.1016/j.vaccine.2013.02.029

[30] Lancefield, R.C. (1933) A Serological Differentiation of Human and Other Groups of Hemolytic Streptococci. Journal of Experimental Medicine, 57, 571-595. http://dx.doi.org/10.1084/jem.57.4.571

[31] Burns, G. and Plumb, J. (2013) GBS Public Awareness, Advocacy, and Prevention: What's Working, What's Not and Why We Need a Maternal GBS Vaccine. Vaccine, 31, D58-D65. http://dx.doi.org/10.1016/j.vaccine.2013.02.039

[32] Chen, V.L., Avci, F.Y. and Kasper, D.L. (2013) A Maternal Vaccine against Group B Streptococcus: Past, Present, and Future. Vaccine, 31, D13-D19. http://dx.doi.org/10.1016/j.vaccine.2012.12.080

[33] Persson, E., Berg, S., Bevanger, L., Bergh, K., Valso-Lyng, R. and Tollfors, B. (2008) Characterisation of Invasive Group B Streptococci Based on Investigation of Surface Proteins and Genes Encoding Surface Proteins. Clinical Microbiology and Infection, 14, 66-73. http://dx.doi.org/10.1111/j.1469-0691.2007.01877.x

[34] Castor, M.L., Whitney, C.G., Como-Sabetti, K., Facklam, R.R., Ferrieri, P., Bartkus, J.M., et al. (2008) Antibiotic Resistance Patterns in Invasive Group B Streptococcal Isolates. Infectious Diseases in Obstetrics and Gynecology, 2008, Article ID: 727505.

[35] Campelo, F.A., Pedrosa, A.C., Antúnez, I.Á. and Capuz, B.L. (2012) Phenotypes and Mechanisms of Resistance to Macrolides and Lincosamides in Streptococcus agalactiae Isolates with Clinical Significance in an Eight-Year Period (2002-2010). Revista Española de Quimioterapia, 25, 42-46.

[36] Famiglietti, A., Quinteros, M., Pedrari, S., Corso, A., Marín, M., Nicola, F., et al. (2004) Actualización del Consenso Sobre las Pruebas de Sensibilidad a los Antimicrobianos en Cocos Grampositivos. SADEBAC-AAM, Buenos Aires.

[37] Mensa, J., García-Vázquez, E. and Vila, J. (2003) Macrólidos, cetólidos y estreptograminas. Enfermedades Infecciosas y Microbiología Clínica, 21, 200-208. http://dx.doi.org/10.1157/13045452

[38] Feng-Ying, C., Parvin, H., Leonard, E., Joseph, B., et al. (2000) Antibiotic Susceptibility Profiles for Group B Streptococci Isolated from Neonates, 1995-1998. Clinical Infectious Diseases, 31, 76-79. http://dx.doi.org/10.1086/313936

[39] CLSI (2013) Performance Standards for Antimicrobial Susceptibility Testing; Sixteenth Informational Supplement. Clinical and Laboratory Standards Institute, 33, M100S23.

[40] Tamariz Ortiz, J., Cruz Quintanilla, J., Atencia Porras, A., Figueroa Tataje, J., Horna Quintana, G. and Guerra Allison, H. (2009) Resistencia a Clindamicina inducida por Eritromicina en Staphylococcus aureus aislados de tres hospitales de Lima, Perú. Acta Médica Peruana, 26, 12-16.

[41] Sambrook, J. and Rusell, D.W. (2001) Molecular Cloning: A Laboratory Manual. 3rd Edition, Cold Spring Harbour Laboratory Press, Cold Spring Harbour, New York, 1-3.

[42] Cariaga Martinez, A.E and Zapata, P.D. (2007) Protocolos de extracción de ADN. In: Zapata, P.D. and Cariaga Martinez, A.E., Eds., El laboratorio de biología molecular, Edición ampliada, Editorial Universitaria de Misiones, Misiones, 23-39.

[43] Edwards, M.S. (2008) Group B Streptococcal Conjugate Vaccine: A Timely Concept for Which the Time Has Come. Human Vaccines, 4, 444-448. http://dx.doi.org/10.4161/hv.4.6.6507

[44] Pettersson, K. (2007) Perinatal Infection with Group B Streptococci. Seminars in Fetal and Neonatal Medicine, 12, 193-197. http://dx.doi.org/10.1016/j.siny.2007.01.010

[45] Poyart, C., Réglier-Poupet, H., Tazi, A., Billoët, A., Dmytruk, N., Bidet, P., et al. (2008) Invasive Group B Streptococcal Infections in Infants, France. Emerging Infectious Diseases, 14, 1647-1649. http://dx.doi.org/10.3201/eid1410.080185

[46] Juncosa-Morros, T., Guardià-Llobet, C., Bosch-Mestres, J., Dopico-Ponte, E., Sanfeliu-Sala, I., Sierra-Soler, M., et al. (2014) Streptococcus Agalactiae Late-Onset Neonatal Infections in Barcelona (1996-2010). Enfermedades Infecciosas y Microbiología Clínica, 32, 574-578. http://dx.doi.org/10.1016/j.eimc.2013.09.012

[47] Liébana-Martos Mdel, C., Cabrera-Alavargonzalez, J., Rodríguez-Granger, J., Miranda-Casas, C., Sampedro-Martínez, A., Gutiérrez-Fernández, J., et al. (2014) Serotypes and Antibiotic Resistance Patterns in Beta-Hemolytic Streptococ- 
cus agalactiae Isolates in Colonized Mothers and Newborns with Invasive Disease. Enfermedades Infecciosas y Microbiología Clínica, 33, 84-88.

[48] Edmond, K.M., Kortsalioudaki, C., Scott, S., Schrag, S.J., Zaidi, A.K., Cousens, S., et al. (2014) Group B Streptococcal Disease in Infants Aged Younger than 3 Months: Systematic Review and Meta-Analysis. The Lancet, 379, 547-556. http://dx.doi.org/10.1016/S0140-6736(11)61651-6

[49] Brzychczy-Wloch, M., Gosiewski, T. and Bulanda, M. (2014) Multilocus Sequence Types of Invasive and Colonizing Neonatal Group B Streptococci in Poland. Medical Principles and Practice, 23, 323-330. http://dx.doi.org/10.1159/000362368

[50] Martins, E.R., Melo-Cristino, J. and Ramirez, M. (2012) Dominance of Serotype Ia among Group B Streptococci Causing Invasive Infections in Nonpregnant Adults in Portugal. Journal of Clinical Microbiology, 50, 1219-1227. http://dx.doi.org/10.1128/JCM.05488-11

[51] Eskandarian, N., Ismail, Z., Neela, V., Van Belkum, A., Desa, M. and Amin Nordin, S. (2014) Antimicrobial Susceptibility Profiles, Serotype Distribution and Virulence Determinants among Invasive, Non-Invasive and Colonizing Streptococcus agalactiae (Group B Streptococcus) from Malaysian Patients. European Journal of Clinical Microbiology \& Infectious Diseases, 34, 579-584. http://dx.doi.org/10.1007/s10096-014-2265-X

[52] Fernandez, M., Hickman, M. and Baker, C. (1998) Antimicrobial Susceptibilities of Group B Streptococci Isolated between 1992 and 1996 from Patients with Bacteremia or Meningitis. Antimicrobial Agents and Chemotherapy, 42, 1517-1519.

[53] Ko, W., Lee, H., Wang, L., Lee, C., Liu, A. and Wu, J. (2001) Serotyping and Antimicrobial Susceptibility of Group B Streptococcus an Eight Years Period in Southern Taiwan. European Journal of Clinical Microbiology \& Infectious Diseases, 20, 334-339. http://dx.doi.org/10.1007/s100960100505

[54] Matsubaraa, K., Nishiyamab, Y., Katayamac, K., Yamamotod, G., Sugiyamae, M., Muraif, T., et al. (2001) Change of Antimicrobial Susceptibility of Group B Streptococci over 15 Years in Japan. Journal of Antimicrobial Chemotherapy, 48, 579-582.

[55] Brimil, N., Barthell, E., Heindrichs, U., Kuhn, M., Lütticken, R. and Spellerberg, B. (2006) Epidemiology of Streptococcus agalactiae Colonization in Germany. International Journal of Medical Microbiology, 296, 39-44. http://dx.doi.org/10.1016/j.ijmm.2005.11.001

[56] Keil, A., Laczeski, M., Oviedo, P., Pegels, E., Quiroga, M., Fonseca, M. and Vergara, M. (2010) Detección del gen rib en cepas invasivas y colonizantes de Streptococcus agalactiae en Misiones. Revista de Ciencia y Tecnología, 14, 25-28.

[57] Johri, A.K., Paoletti, L.C., Glaser, P., Dua, M., Sharma, P.K., Grandi, G., et al. (2006) Group B Streptococcus: Global Incidence and Vaccine Development. Nature Reviews Microbiology, 4, 932-942. http://dx.doi.org/10.1038/nrmicro1552

[58] Campelo, F., Pedrosa, A., Antúnez, I. and Capuz, B. (2012) Phenotypes and Mechanisms of Resistance to Macrolides and Lincosamides in Streptococcus agalactiae Isolates with Clinical Significance in an Eight-Year Period (2002-2010). Revista Española de Quimioterapia, 25, 42-46.

[59] Hsueh, P.R., Teng, L.J., Lee, L.N., Ho, S.W., Yang, P.C. and Luh, K.T. (2001) High Incidence of Erythromycin Resistance among Clinical Isolates of Streptococcus agalactiae in Taiwan. Antimicrobial Agents and Chemotherapy, 41, 3205-3208. http://dx.doi.org/10.1128/AAC.45.11.3205-3208.2001

[60] Leclercq, R. and Courvalin, P. (1991) Bacterial Resistance to Macrolide, Lincosamide, and Streptogramin Antibiotics by Target Modification. Antimicrobial Agents and Chemotherapy, 35, 1267-1272. http://dx.doi.org/10.1128/AAC.35.7.1267

[61] Dela Cruz, W., Richardson, J., Broestle, J., Thornton, J. and Danaher, P. (2007) Rapid Determination of Macrolide and Lincosamide Resistance in Group B Streptococcus Isolated from Vaginal-Rectal Swabs. Infectious Diseases in Obstetrics and Gynecology, 2007, Article ID: 46581.

[62] Morozumi, M., Wajima, T., Kuwata, Y., Chiba, N., Sunaoshi, K., Sugita, K., et al. (2014) Associations between Capsular Serotype, Multilocus Sequence Type, and Macrolide Resistance in Streptococcus agalactiae Isolates from Japanese Infants with Invasive Infections. Epidemiology and Infection, 142, 812-819. http://dx.doi.org/10.1017/S0950268813001647

[63] Tazi, A., Morand, P.C., Réglier-Poupet, H., Dmytruk, N., Billoët, A., Antona, D., et al. (2011) Invasive Group B Streptococcal Infections in Adults, France (2007-2010). Clinical Microbiology and Infection, 17, 1587-1589. http://dx.doi.org/10.1111/j.1469-0691.2011.03628.x

[64] Von Both, U. (2003) A Serotype V Clone Is Predominant among Erythromycin-Resistant Streptococcus agalactiae Isolates in a Southwestern Region of Germany. Journal of Clinical Microbiology, 41, 2166-2169. http://dx.doi.org/10.1128/JCM.41.5.2166-2169.2003

[65] Papasergi, S., Lanza Cariccio, V., Pietrocola, G., Domina, M., D’Aliberti, D., Trunfio, M.G., et al. (2013) Immunogenic Properties of Streptococcus agalactiae FbsA Fragments. PLoS ONE, 8, e75266.

http://dx.doi.org/10.1371/journal.pone.0075266 